\title{
Influence of Hydrological Variables on Macrophytes in a Black Water River Ecosystem
}

\author{
*1'ANWANA, ED; ${ }^{1}$ OGBEMUDIA, FO; *2ITA, RE; ${ }^{3}$ SUNDAY, PE \\ ${ }^{I}$ Department of Botany and Ecological Studies, University of Uyo, Uyo, Nigeria \\ ${ }^{* 2}$ Department of Biological Sciences, Ritman University, Ikot Ekpene, Nigeria \\ ${ }^{3}$ Centre for Wetlands and Waste Management, University of Uyo, Uyo, Nigeria \\ *Corresponding Author Email: alwaizfwesh247@yahoo.com
}

\begin{abstract}
This study assessed the influence of hydrological variables on macrophytes in a Black Water River ecosystem of Enyong River in Itu and Ibiono Local Government Areas of Akwa Ibom and Cross Rivers States, Nigeria. Four vegetation plots were chosen and in each of the plots, four belt transect were laid. In each transect, macrophyte were systematically sampled in four $10 \mathrm{~m} \times 10 \mathrm{~m}$ quadrat at regular intervals. Macrophytes were identified to species level and their frequency and density determined. Water samples were obtained in each quadrat where the macrophytes were sampled and analyzed for their physicochemical properties using standardized methods. Altogether, 10 macrophyte

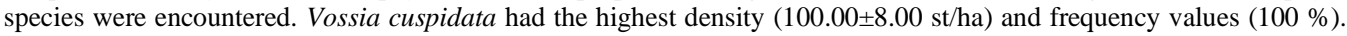
Sacciolepis africana had the least density of $7.10 \pm 0.45$ st/ha while Ludwigia octovalvis, Persicaria senegalensis, and Sacciolepis africana had the least frequency of $25 \%$, respectively. The $\mathrm{pH}$ of the water was strongly acidic (5.54 \pm 0.03$)$, electrical conductivity was low $(20.00 \pm 5.77 \mu \mathrm{s} / \mathrm{cm})$, temperature $\left(29.00 \pm 1.10^{\circ} \mathrm{C}\right)$, Dissolved Oxygen (DO) $(9.20 \pm 0.12$ $\mathrm{mg} / \mathrm{l})$ and turbidity $(7.10 \pm 0.06 \mathrm{NTU})$ values were high while Biological Oxygen Demand (BOD) (2.00 $\pm 0.29 \mathrm{mg} / \mathrm{l})$ Total Dissolved Solids (TDS) $(10.00 \pm 0.29 \mathrm{mg} / \mathrm{l})$ and Total Suspended Solids (TSS) were low $(5.00 \pm 1.15 \mathrm{mg} / \mathrm{l})$. Water Nutrients followed this decreasing order; chloride $(3.55 \pm 0.02 \mathrm{mg} / \mathrm{l})>$ nitrate $(2.45 \pm 0.03 \mathrm{mg} / \mathrm{l})>$ sulphate $(2.02 \pm 0.06 \mathrm{mg} / \mathrm{l})>$ phosphate $(0.08 \pm 0.01 \mathrm{mg} / \mathrm{l})$ and sulphide $(0.03 \pm 0.02 \mathrm{mg} / \mathrm{l})$. Heavy metals also followed this descending order; $\mathrm{Pb}$ $(0.50 \pm 0.03 \mathrm{mg} / \mathrm{l})>\mathrm{Zn}(0.07 \pm 0.02 \mathrm{mg} / \mathrm{l})>\mathrm{Cu}(0.03 \pm 0.02 \mathrm{mg} / \mathrm{l})$. Canonical Correspondence Analysis delineated 11 hydrological variables (temperature, $\mathrm{pH}$, sulphate, turbidity, phosphate, BOD, nitrate, DO, TDS, sulphide and TSS) which exerted great influence on macrophyte distribution. V. cuspidata had affinity to $\mathrm{pH}$ and temperature, Sacciolepis africana had affinity to turbidity and BOD, Ludwigia octovalvis and Nymphaea lotus had affinity to sulphate and chloride, respectively, while Ipomoea aquatica and Alternanthera sessils had affinity to phosphate. On the other hand, Persicaria senegalensis, Salvinia molesta, Azolla pinnata and Ceratophyllum demersum had affinities to sulphide, DO, TSS and TDS, respectively. Since hydrological variables regulate macrophyte diversity and distribution, this study calls for consistent, monitoring and management of this ecosystem against future environmental changes.
\end{abstract}

\section{DOI: https://dx.doi.org/10.4314/jasem.v25i2.3}

Copyright: Copyright (c) 2021 Anwana et al. This is an open access article distributed under the Creative Commons Attribution License (CCL), which permits unrestricted use, distribution, and reproduction in any medium, provided the original work is properly cited.

Dates: Received: 12 December 2020; Revised: 26 January 2021; Accepted: 12 February 2021

Keywords: Aquatic plants, Black water, Canonical Correspondence Analysis, Ordination

Macrophytes are important components of many aquatic ecosystems. Their roles in these ecosystems cannot be overlooked as they provide numerous ecological functions such as being primary producers along food chains, providing shelter for periphyton, algae, zooplankton and assisting in nutrient cycling (Hatton-Ellis et al., 2003; Lacoul and Freedman, 2006). Some of them are directly involved in provision of biomass and building materials (Egertson et al., 2004, Bornette and Puijalon, 2011). Based on their importance, their sustainability is very pivotal in aquatic ecosystem. Be that as it may, for this to be achieved, there is need to study the intricate relationships between these plants and the environment. Macrophytes are very sensitive to the environmental conditions which they inhabit and these influence and exert great impacts on their establishments, proliferations and developments (Baattrup-Pedersen and Riis, 1999; Lacoul and Freedman, 2006). These environmental conditions include sediments, water and air. In this study, the primary focus is on hydrology. The abundance and distributions of macrophytes in lotic ecosystems are not determined by just one hydrological factor but rather by constellations of complex hydrological variables. However, these hydrological variables vary across ecosystems. While Clarke and Wharton (2001), Schneider and Melzer (2004), Baldy et al. (2007) stressed on nutrients as being influential on macrophyte distribution, others cited various chemicals present in the water (Mosisch and Arthington, 1998; Samecka-Cymerman and Kempers, 2007). In addition, Baattrup-Pedersen et al. (2006) expressed concerns over anthropogenic perturbations 
impeding the establishments of pristine macrophyte communities. These disturbances are expressed in the form of eutrophication, water pollution, changes in hydrological regime due to dams and channels construction and decline in weeds as a consequence of cutting (Baattrup-Pedersen et al., 2003; Daniel et al., 2005; Hilton et al., 2006 and Catford et al., 2011). The importance of these hydrological variables on macrophytes are strong because they are the major forces responsible for structuring macrophyte communities (De Wilde et al., 2016; Riera et al., 2017). Different types of macrophyte (e.g., emergent, rooted submerged, and free-floating) utilize environmental resources (nutrients and light) in specific ways and they also differ in their response to environmental changes (Akasaka and Takamura, 2011; Netten et al., 2011). For example, while submerged plants are strongly dependent on underwater light (Luhtala et al., 2017), free-floating plants have primacy in obtaining this resource (Lacoul and Freedman, 2006), but are more affected by availability of nutrients in the water column (Giblin et al., 2014). In contrast, emergent macrophytes in their early developmental stages are influenced by light availability and they obtain nutrients from sediment, being expected as less dependent on water quality than other life forms (Akasaka et al., 2010; Akasaka and Takamura, 2011). Nevertheless, Partanen et al. (2009) reported that changes in water quality can directly or indirectly affect emergent macrophytes through sedimentation of organic matter. Despite the underlining importance of hydrological variables on macrophyte distribution, very few researches have been carried out on the influence of water variables on macrophyte composition as well as the affinity each species has with hydrological variables. This being that, vast studies on macrophytes have only centered on the pedological profile as being influential on their distribution. In this ecosystem, only studies relating to water qualities and macrophyte diversity have been documented, hence, information on which water variables affect or regulate macrophyte abundance and distribution are scarce. Also, it is worthy of note that this ecosystem has areas with white and black waters, with more luxuriant macrophytes in the black water. This, however, is mind-boggling, and therefore necessitates a qualitative assessment of the black water and the affinity of each species to these water variables. Our aim is to delineate the main hydrological determinants of individual macrophytes of Enyong River in Itu and Ibiono Local Government Areas of Akwa Ibom and Cross Rivers States, Nigeria.

\section{MATERIALS AND METHODS}

Study Area: This study was carried out in a Black Water area (Latitude $5^{\circ} 19^{\prime} 55^{\prime \prime} \mathrm{N}$ and Longitude $7^{\circ}$
55'56" E) of Enyong River. Enyong River lies between Itu and Ibiono Local Government Areas both in Akwa Ibom State as well as the western parts of Cross Rivers State. Enyong River lies within latitudes $5^{\circ} 25^{\prime}$ and $5^{\circ} 10 \mathrm{~N}$ and longitudes $8^{\circ} 10^{\prime}$ and $7^{\circ} 35 \mathrm{E}$. The area is well represented by structurally controlled ridges, denudation hills, extensive wetlands and alluvial plains forming soil covers of silty clay, sandy and heavily weathered loamy and alluvium. The area enjoys tropical climate and the temperature ranges from 26 to $32^{\circ} \mathrm{C}$. The fluctuations in temperature are fairly uniform in character, except during the dry months when the rise in temperature is higher than it is during the long wet period (eight months-March to October) and the level of humidity is high (84\%) due to close proximity to the main Cross River Channel. The average annual rainfall in the basin is $2200 \mathrm{~mm}$ with maximum contribution from southwest tropical maritime air-mass.

Macrophyte Sampling and Water Sampling: In this study, four vegetation plots were used. In each of the plots, four belt transects were laid and in each transect, macrophytes were sampled systematically using four $10 \mathrm{~m} \times 10 \mathrm{~m}$ quadrats spaced at regular intervals of 20 $\mathrm{m}$. In each quadrat, the density and frequency of the macrophytes were enumerated. In each quadrat where the macrophyte species occurred, water samples were also collected, stored in labelled sampling bottles, and taken to the laboratory for their physicochemical analysis.

Determination of Quantitative Variables: Density: The density of each macrophyte species was estimated by enumerating all plants present in each plot. The number of individuals of a species was taken as a proportion of the number of transects to give a mean of species. The mean was then taken as a proportion of the area of the quadrat to give density in $\mathrm{m}^{2}$ which was multiplied by $10,000 \mathrm{~m}^{2}$ to give density per hectare

Frequency: The frequency of each macrophyte was calculated thus;

$$
F=\frac{Q_{\text {a species }}}{Q_{\text {total species }}} \times 100
$$

Where $\mathrm{F}=$ frequency; $\mathrm{Q}_{\mathrm{a} \text { species }}=$ number of occupied quadrant for a species; $Q_{\text {total species }}=$ Total number of quadrants thrown

Physicochemical Analysis of Water: Electrical conductivity, Temperature, $\mathrm{pH}$, and total dissolved solids were measured in-situ using a portable EC/ temperature/pH / TDS / combined HANNA, HI 991301 model instrument. The probe was immersed in 
the water to the indicated mark, and the reading as displayed on the screen was read off directly. An oxygen meter of the model Hanna H198186 was used for measuring dissolved oxygen by dipping the electrode into the water and the reading noted for a stable value. Biochemical oxygen demand (BOD) was determined by conventional method according to Association of Official Analytical Chemists (AOAC, 2000). Total suspended solids was obtained by the filtration method according to APHA (2005). The turbidity of the water was determined with the use of portable turbidity meter from Hanna instruments, HI 98703. Sulphide, Chloride, nitrate, sulphate and phosphate were determined using iodimetry method, Argentometric titration, spectrophotometric method, turbidimetric method, and colorimetry method, respectively, as outlined by APHA (2005). Pb, Zn and $\mathrm{Cu}$ were determined using The Inductively Coupled Plasma Optical Emission Spectrophotometry (ICPOES 720).

Statistical Data Analysis: Means and standard errors of triplicates were computed using Graphpad Prism (6.0). Canonical Correspondence Analysis was performed using Paleontological Statistics (PAST 3.0).

\section{RESULTS AND DISCUSSION}

Compendium of the Extant Macrophyte Species: The compendium of the macrophytes in the ecosystem is presented in Table 1. A total of ten macrophyte species belonging to 9 distinct families were encountered. Vossia cuspidata had the highest frequency (100\%) and density (100.00 $\pm 8.00 \mathrm{st} / \mathrm{ha})$. Ludwigia octovalvis (25\%), Persicaria senegalensis $(25 \%)$ and Sacciolepis africana (25\%) had the least frequency while Sacciolepis africana had the least density of $7.10 \pm 0.45 \mathrm{st} / \mathrm{ha}$. The percentage composition in terms of the habit of the macrophytes followed this decreasing trend; emergent $(50 \%)>$ floating-leaved $(30 \%)>$ free floating $(1 \%)$ and submerged $(1 \%)$.

Physicochemical Characterization of the Water: The physicochemical properties of the water is presented

Table 1: Compendium of the Extant Macrophyte Species

\begin{tabular}{|c|c|c|c|c|}
\hline Species & Family & Habit & Frequency $(\%)$ & Density (st/ha) \\
\hline Alternanthera sessils (L.) R.Br. ex DC. & Amaranthaceae & Emergent & 50 & $12.00 \pm 1.32$ \\
\hline Azolla pinnata $\mathrm{R} . \mathrm{Br}$. & Salviniaceae & Free floating & 75 & $59.10 \pm 4.62$ \\
\hline Ipomoea aquatica Forssk. & Convolvulaceae & Floating-leaved & 75 & $70.51 \pm 5.63$ \\
\hline Ludwigia octovalvis (Jacq.) P.H. Raven & Onagraceae & Emergent & 25 & $9.70 \pm 0.62$ \\
\hline Nymphaea lotus L. & Nymphaeaceae & Floating-leaved & 50 & $15.50 \pm 1.49$ \\
\hline Salvinia molesta D. Mitch. & Salviniaceae & Floating-leaved & 75 & $61.50 \pm 4.12$ \\
\hline Vossia cuspidata (Roxb.) Griffith. & Poaceae & Emergent & 100 & $100.00 \pm 8.00$ \\
\hline
\end{tabular}

in Table 2. The $\mathrm{pH}$ of the water was strongly acidic (5.54 \pm 0.03$) \quad$ while electrical conductivity, temperature, turbidity, total dissolved solids and total suspended solids had values of $20.00 \pm 5.77 \mu \mathrm{s} / \mathrm{cm}$, $29.00 \pm 1.10^{\circ} \mathrm{C}, 7.10 \pm 0.06 \mathrm{NTU}, 10.00 \pm 0.29 \mathrm{mg} / \mathrm{l}$ and $5.00 \pm 1.15 \mathrm{mg} / \mathrm{l}$. Dissolved oxygen was high $(9.20 \pm 0.12 \mathrm{mg} / \mathrm{l})$ while Biochemical Oxygen Demand was low $(2.00 \pm 0.29 \mathrm{mg} / \mathrm{l})$. Chloride, nitrate, sulphate, phosphate and sulphide recorded mean values of $3.55 \pm 0.02 \mathrm{mg} / \mathrm{l}, 2.45 \pm 0.03 \mathrm{mg} / \mathrm{l}, 2.02 \pm 0.06 \mathrm{mg} / \mathrm{l}$, $0.08 \pm 0.01 \mathrm{mg} / \mathrm{l}$ and $0.03 \pm 0.02 \mathrm{mg} / \mathrm{l}$. The heavy metals followed this decreasing trend; $\mathrm{Pb}(0.50 \pm 0.03 \mathrm{mg} / \mathrm{l})>$ $\mathrm{Zn}(0.07 \pm 0.02 \mathrm{mg} / \mathrm{l})>\mathrm{Cu}(0.03 \pm 0.02 \mathrm{mg} / \mathrm{l})$.

Influence of Water Variables on Macrophyte Distribution: The influence of hydrological variables on the occurrence and distribution of macrophyte species was established using Canonical Correspondence Analysis (CCA). The CCA ordination of macrophytes to hydrological variables is shown in Figure 1 while the eigen values and the percentage variances of the main axes are presented in Table 3. This was carried out using the density values of the macrophytes across the various sampled plots. From the result, the CCA ordination of the first two (2) canonical axes accounted for $100 \%$ of the total variance in the data set. Information on the variations in macrophyte distribution along hydrological gradients are borne by these axes. The cumulative percentage of the first two axes explained $100 \%$ of the total variance (Table 3). In the triplot, small thick circles represent the macrophyte species while the arrow lines represent the water variables (vectors) for which the species had affinity for. The length of the lines is relational to the magnitude of change due to hydrological variables while the direction of the lines show their axis correlation. Longer lines show high influence of hydrological variables on the establishment of macrophytes while shorter lines indicate a low influence of these variables on the macrophytes' establishment. The distance of a named species from the vector lines entails its preference or affinity to the vector. 
The floristic anthology of the black water ecosystem showed various types of macrophytes (emergent, free floating, floating-leaved and submerged) occupying different niches in the ecosystem. This suggests that macrophytes rarely occur in monospecific stands but rather, they establish an easily recognizable formations and assemblages which are made up of species of various life forms. The number of macrophytes in this river is low when comparison is made with numbers reported by scholars in other lotic ecosystems. For instance, Adhishwar and Choudhary (2013) reported a total 137 macrophytes in Gogabil lake wetland, Bihar, India Rameshkumar et al. (2019) reported 15 macrophytes in a seasonal Tharavai wetland, south coast of India.

The low macrophyte diversity in this study may be affiliated to the heterogeneity of the ecosystem, anthropogenic perturbations and pollution (eutrophication) (Ogbemudia and Ita, 2016; Rameshkumar et al., 2019). Macrophytes with high and low density values may have revealed their different regenerative abilities and adaptation levels to the prevailing environmental conditions. Macrophytes with high and low frequency values are indicative of a wide and ecological amplitudes. Species with close frequency values may insinuate high competition among taxa for environmental resources. The conspicuous dominance of Vossia cuspidata in this ecosystem synchronizes with the findings of Ogbemudia and Ita (2016). According to them, the presence of this macrophyte in increasing numbers is not unprecedented but rather it is very typical of most tropical wetlands. Aside from being commonly found in riverine wetlands, its efficient reproductive and better dispersal abilities may further account for its cosmopolitan nature in the ecosystem. In affirming this, Ogbemudia and Ita (2016) stressed that during the dry season where there is a receding water level, the vegetative parts of Vossia cuspidata quickly emerge from the enriched and exposed mud, with a fast regeneration ability to withstand the prevailing water logging conditions in the wet season.

Santamaria (2002) adds that plants with such good dispersal and regenerative abilities are likely to display phenotypic plasticity and polymorphism to environmental factors. The high ranking of emergent macrophytes above other life forms in this studies corroborates with the findings of Ghosh and Biswas (2015), Subhas et al. (2016). Their abundance in this ecosystem is not unconnected to the fact that they make use of all three possible states while growing with their roots in sediment, beneath water and their photosynthetic parts in the air. This mechanism gives them an edge over other life forms and makes them more productive.

Table 2: Physicochemical Characterization of the Water

\begin{tabular}{lll}
\hline Parameters & Value & WHO $(\mathbf{2 0 1 1})$ \\
\hline $\mathrm{pH}$ & $5.54 \pm 0.03$ & $6.5-9.2$ \\
Electrical & $20.00 \pm 5.77$ & 1500 \\
conductivity $(\mu \mathrm{s} / \mathrm{cm})$ & & \\
Temperature $\left({ }^{\circ} \mathrm{C}\right)$ & $29.00 \pm 1.1$ & $20-30^{\circ} \mathrm{C}$ \\
Turbidity $(\mathrm{NTU})$ & $7.10 \pm 0.06$ & 5 \\
TDS $(\mathrm{mg} / \mathrm{l})$ & $10.00 \pm 0.29$ & 250 \\
$\mathrm{TSS}(\mathrm{mg} / \mathrm{l})$ & $5.00 \pm 1.15$ & 50 \\
$\mathrm{DO}(\mathrm{mg} / \mathrm{l})$ & $9.20 \pm 0.12$ & 5.0 \\
$\mathrm{BOD}(\mathrm{mg} / \mathrm{l})$ & $2.00 \pm 0.29$ & 10 \\
$\mathrm{Chloride}(\mathrm{mg} / \mathrm{l})$ & $3.55 \pm 0.02$ & 250 \\
Nitrate $(\mathrm{mg} / \mathrm{l})$ & $2.45 \pm 0.03$ & 50 \\
Sulphate $(\mathrm{mg} / \mathrm{l})$ & $2.02 \pm 0.06$ & 500 \\
Phosphate $(\mathrm{mg} / \mathrm{l})$ & $0.08 \pm 0.01$ & 5 \\
Sulphide $(\mathrm{mg} / \mathrm{l})$ & $0.03 \pm 0.02$ & \\
$\mathrm{~Pb}(\mathrm{mg} / \mathrm{l})$ & $0.50 \pm 0.03$ & 0.01 \\
$\mathrm{Zn}(\mathrm{mg} / \mathrm{l})$ & $0.07 \pm 0.02$ & 5.00 \\
$\mathrm{Cu}(\mathrm{mg} / \mathrm{l})$ & $0.03 \pm 0.02$ & 2 \\
\hline \multicolumn{4}{l}{}
\end{tabular}

Table 3: Eigenvalues, species-environment correlation coeffiients,

\begin{tabular}{cccl}
\multicolumn{3}{c}{ and cumulative percentage for the first two axes } \\
\hline 1 & Eigenvalue & $\begin{array}{l}\text { Variance } \\
\text { explained }\end{array}$ & $\begin{array}{l}\text { Cumulative } \\
\text { Variance }\end{array}$ \\
\hline 1 & 0.048711 & 62.12 & 62.18 \\
2 & 0.029709 & 37.88 & 100 \\
\hline
\end{tabular}

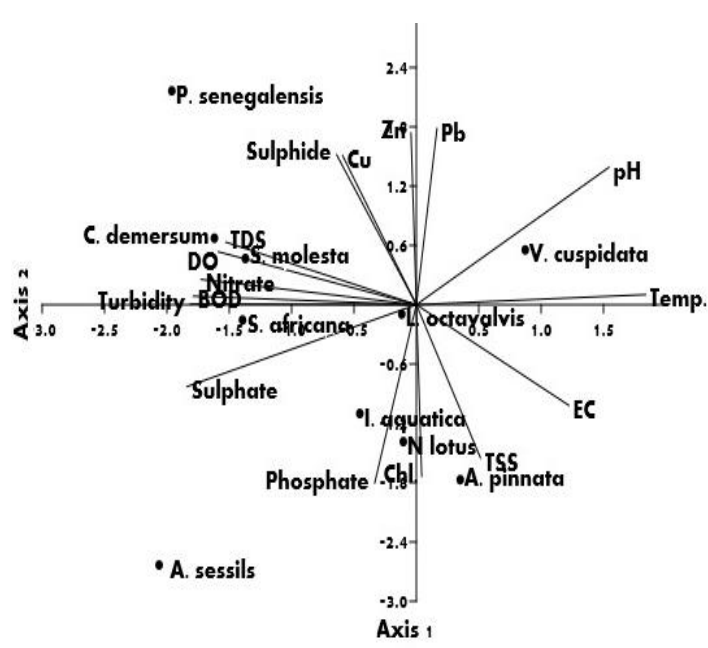

Fig 1: Canonical Correspondence Analysis for water-macrophyte variables

The strongly acidic $\mathrm{pH}$ might have been due to high decomposition of organic matter rich in acidified substances (humic and fulvic acids). The low electrical conductivity value in this study was expected as this is a fresh water ecosystem. Turbidity was above the WHO permissible limit and this may be attributed to the ecosystem which was a black water and high intrusion of allochthonous substances (suspended and colloidal matters) into the water (Akpan, 2004). Total dissolved solids and total suspended solids were below their permissible limits. This may be attributed to low inputs of substances rich in these solids in the 
ecosystem. High dissolved oxygen in this study may be linked to high photosynthetic activities by green plants which release oxygen into the water (Aguigwo, 1998; Ekpo et al., 2012; Kotadiya and Acharya, 2014). Essien-Ibok et al. (2010) also linked high dissolved oxygen to increased flow that enabled diffusion and mixing of atmospheric oxygen into the water, as opposed to stagnation and increased organic load (mainly as leaf litter) into the water whose decomposition increase oxygen depletion. The low BOD levels in the water is suggestive of low intrusion and decomposition of organic wastes in the water. Low levels of chloride, nitrate, sulphate, phosphate and sulphide accentuate low nutrient inputs from runoffs of agricultural and domestic effluent into the water. The high ranking of $\mathrm{Pb}$ among the heavy metals is indicative of intense anthropogenic disturbances. According to Ter Braak (1988) and Ita et al. (2019), the adoption of Canonical Correspondence Analysis reveals patterns of species assemblages in response to environmental factors. This is visible in this study. The hydrological variables that were very influential on the distribution of macrophytes in this ecosystem were; temperature, $\mathrm{pH}$, sulphate, turbidity, phosphate, Biochemical Oxygen Demand, nitrate, Dissolved Oxygen (DO), Total Dissolved Solids (TDS), sulphide and Total Suspended Solids (TSS). V. cuspidata had great affinity to $\mathrm{pH}$ and temperature of the water. This may entail that these parameters were optimal for its growth and proliferations in the ecosystem. The importance of these variables to plant growth cannot be overlooked. For instance, Wrona et al. (2006) and Meis et al. (2009) asserted that temperature regulates flowering, phenology, uptake of nutrients and metabolic activities (respiration and photosynthesis). Riis et al. (2012) also reported that temperature favours the growth enhancement of certain macrophytes in terms of height, length of shoot, biomass production and surface area of leaf. The profuse dominance of $V$. cuspidata with affinity to temperature in this ecosystem validate the findings of Rothausler et al. (2011) and Riis et al. (2012) that emergent macrophytes under increased temperature, will become more abundant as the reproductive capacity (sporophyte growth and spore production) will be enhanced. The bonding of this species to $\mathrm{pH}$ may further confirm the influence of climatic factor on growth of macrophytes. $\mathrm{pH}$ on the other hand has been reported to be the determinant of the productivity of a site and in the segregation of plant groups (Dong et al., 2014; Ita et al., 2019). This is quite true at it regulates the availability of nutrients required by plants. The affinities of L. octovalvis to sulphate, N. lotus to chloride, I. aquatica and A. sessils to phosphate may highlight the water nutrient demands of these macrophytes for growth and development. Nutrients are very vital for the growth of macrophytes. Frankouich et al. (2006) in affirming this reported that the growth and distribution macrophytes are allied with nutrient rich environments. Hence, the essentiality of the aforementioned nutrients to macrophytes cannot be underestimated. For instance, chloride has been reported to play important roles in photosynthesis, disease suppression, osmotic and stomatal adjustment (Chen et al., 2010). Sulphur taken up in the form of sulphate by plants plays critical role in protein, chlorophyll and amino acids syntheses (Jamal et al., 2010). Phosphorus which is taken as phosphate by plants, plays crucial functions in being the constituent of ATP, RNA and DNA (Brown and Weselby, 2010). The preference of $P$. senegalensis to salt-rich site may accentuate its affinity to sulphide. The bonding of $S$. molesta to dissolved oxygen may point to the fact that this macrophyte thrived well in sites devoid of pollution. The affinity of S. africana to turbidity and Biological Oxygen Demand may expound its preference to sites that are murky and polluted with organic wastes. It may also portray its tolerance to pollution. The segregation and bonding of $A$. pinnata and $C$. demersum to Total Suspended Solids and Total Dissolved Solids may also underline their preference to hazy and less transparent sites in the water brought about by decaying substances, suspension of silt, clay inorganic and organic materials.

Conclusion: This study revealed that the occurrence and assemblages of macrophytes in various lifeforms in this ecosystem are regulated and influenced greatly by multi-hydrological variables. The affinities of macrophytes to hydrological variables and revealed their preferences and segregations to sites where these variables are highly influential in the ecosystem. From this, we conclude that hydrological factors are important drivers of macrophyte communities with regards to their climatic and nutrient requirements spatially.

\section{REFERENCES}

Adhishwar, A. K; Choudhary, S K (2013). Diversity of macrophytic species of Gogabil lake wetland in Katihar, Bihar, India. Ecology, Environment and Conservation, 19(4):1165-1172

Aguigwo, J N (1998). Studies on the PhysicoChemical Parameters and Plankton Productivity of a Productive Stream. Journal of Aquatic Science, 13: 9-13

Akasaka, M; Takamura, N (2011). The relative importance of dispersal and the local environment 
for species richness in two aquatic plant growth forms. Oikos, 120: 38-46.

Akasaka, M; Takamura, N H M; Yasuro, K (2010). Effects of land use on aquatic macrophyte diversity and water quality of ponds. Freshwater Biology, 55: 909-922.

Akpan, A W (2004). The Water Quality of some Tropical Fresh Water Bodies in Uyo (Nigeria) Receiving Municipal Effluents, Slaughterhouse Washings and Agricultural Land Drainage. The Environmentalist, 24(1): 49 - 55.

Alahuhta, J; Heino, J (2013). Spatial extent, regional specificity and metacommunity structuring in lake macrophytes. Journal of Biogeography, 40: 1572-1582.

AOAC (2000). Official methods of analysis of AOAC. International $17^{\text {th }}$ edition; Gaithersburg, MD, USA Association of Analytical Communities.

APHA (2005). Standard Methods for the examination of Water and Waste Water. 21 ${ }^{\text {st }}$ edition., New York: American Public Health Association. 1498 p.

Baattrup-Pedersen, A; Riis, T (1999). Macrophyte diversity and composition in relation to substratum characteristics in regulated and unregulated Danish streams. Freshwater Biology, $42: 375-85$.

Baattrup-Pedersen, A; Larsen, S E; Riis, T (2003). Composition and richness of macrophyte communities in small Danish streams influence of environmental factors and weed cutting. Hydrobiologia, 495: 171-179.

Baattrup-Pedersen, A; Szoszkiewicz, K; Nijboer, R; O'Hare, M; Ferreira, T (2006). Macrophyte communities in unimpacted European streams: variability in assemblage patterns, abundance and diversity. Hydrobiologia, 566: 179-196.

Baldy, V; Trémolières, M; Andrieu, M; Belliard, J (2007). Changes in phosphorus content of two aquatic macrophytes according to water velocity, trophic status and time period in hardwater streams. Hydrobiologia 575: 343-351.

Bornette, G; Puijalon, S (2011). Response of aquatic plants to abiotic factors: a review. Aquatic Science, 73: 1-14.
Brown, D; Weselby, C (2010). NASA-funded research discovers life built with toxic chemical. NASA Feature. Accessed October 17, 2020. Retrieved from: http://www.nasa.gov/

Catford, J A; Downes, B J; Gippel, C J; Vesk, P A (2011). Flow regulation reduces native plant cover and facilitates exotic invasion in riparian wetlands. Journal of Applied Ecology, 48: 432442.

Chen, W; He, ZL; Yang, XE; Mishra, S; Stofella, P J (2010). Chlorine nutrition of higher plants: progress and perspectives. Journal of Plant Nutrition, 33: 943 - 952

Clarke, S J; Wharton, G (2001). Sediment nutrient characteristics and aquatic macrophytes in lowland English Rivers. Science of the Total Environment, 266: 103 - 112.

Cronk, J K; Fennessy, M S (2001). Wetland Plants: Biology and Ecology. Boca Ratón, FL: Lewis Publishers.

Daniel, H; Bernez, I; Haury, J (2005). The ability of aquatic macrophytes to assess fish farm pollution in two salmon rivers. Hydrobiologia, 551: 183191.

De Wilde, M; Puijalon, S; Bornette, G (2016). Sediment type rules the response of aquatic plant communities to dewatering in wetlands. Journal of Vegetation Science 28: 172-183.

Dong, L; Xu, LG; Xu, JX (2014). Effects of Soil Environmental Factors on Vegetation Distribution in Shoaly Wetlands Typical to Poyang Lake. Acta PedologicaSinica, 51(3):618626.

Egertson, CJ; Kopaska, JA; Downing, JA(2004). A century of change in macrophyte abundance and composition in response to agricultural eutrophication. Hydrobiologia, 524: 145-156.

Ekpo, IE; Chude, LA; Onuoha, G C(2012). Studies on the Physico-Chemical Characteristics and Nutrients of a Tropical Rainforest River Southeast, Nigeria. International Journal of the Bioflux Society, 5(3): 142 - 162.

Essien-Ibok, MA; Akpan, AW; Udo, MT; Chude, LA; Umoh, IA; Asuquo, IE (2010). Seasonality in the Physico-chemical Characteristic of Mbo River, 
Akwa Ibom State, Nigeria. Nigerian Journal of Agriculture and Food Environment, 6: 60 - 72.

Frankouich TA; Gainer, E E; Zieman, JC; Wachnick A H (2006). Spatial and temporal distribution of epiphytic diatoms growing on Thlassic testudinum Banks ex Konigh. Relationship to waters quality. Hydrobiology, 560: 259 - 271.

Ghosh, D; Biswas, J K (2015). Biomonitoring macrophytes diversity and abundance for rating aquatic health of an Oxbow lake ecosystem in Ganga River Basin. American Journal of Phytomedicine and Clinical Therapeutics, 3 (10): $602-621$.

Giblin, S M; Houser, J N; Sullivan, JF; Langrehr, HA; Rogala, JT; Campbell, B D (2014). Thresholds in the response of free-floating plant abundance to variation in hydraulic connectivity, nutrients, and macrophyte abundance in a large floodplain river. Wetlands, 34: 413-425.

Hatton-Ellis, TW; Grieve, N; Newman, J (2003). Ecology of watercourses characterized by Ranunculion fluitantis and CallitrichoBatrachion vegetation. Conserving Natura 2000 rivers ecology series, vol. 11. Peterborough: English Nature.

Hilton, J.; O'Hare, M; Bowes, MJ; Jones JI (2006). How green is my river? A new paradigm of eutrophication in rivers. Science of the Total Environment, 365: 66-83.

Ita, RE; Ogbemudia, FO; Kekere, O; Udo, ED (2019). Plant species as influenced by soil relations in a mangrove ecosystem of lower IMO river estuary, Niger Delta, Nigeria. MOJ Ecology \& Environmental Sciences, 4 (3): $92-98$.

Jamal, A; Moon, YS; Abdin, MZ (2010). Sulphur-a general overview and interaction with nitrogen. Australian Journal of Crop Science, 4(7): 523529.

Kotadiya, NG; Acharya, CA (2014). An assessment of lake water quality index of Manipu lake of district Ahmedabad. Gujarat. International Journal of Science and Research, 3(4):448-450.

Lacoul, P; Freedman, B (2006). Environmental influences on aquatic plants in freshwater ecosystems. Environment Reviews, 14: 89 - 136.
Luhtala, H; Tolvanen, H; Kulha, N; Risto, K. (2017). The effect of underwater light availability dynamics on benthic macrophyte communities in a Baltic Sea archipelago coast. Hydrobiologia, 776: 277-291.

Meis, S; Thackrey, SJ; Jones, ID (2009). Effects of recent climate change on phytoplankton phenology in a temperate lake. Freshwater Biology, 54: 1888 - 1898.

Mosisch, TD; Arthington AH (1998). The impacts of power boating and water skiing on lakes and reservoirs. Lakes \& Reservoirs: Research and Management, 3: 1-17.

Netten, JC; Zuidam, J; Kosten, S; Peeters, ET (2011). Differential response to climatic variation of freefloating and submerged macrophytes in ditches. Freshwater Biology, 56: 1761-1768.

Ogbemudia FO; Ita RE (2016). Macrophyte abundance and water quality status of three impacted inlet streams along Ikpa River Basin, Akwa Ibom State, Nigeria. Tropical Freshwater Biology, 25: $67-84$.

Partanen, S; Luoto, M; Hellsten, S (2009). Habitat level determinants of emergent macrophyte occurrence, extension and change in two large boreal lakes in Finland. Aquatic Botany, 90: 261268.

Rameshkumar, S; Radhakrishnan, K; Aanand, S; Rajaram, R (2019). Influence of physicochemical water quality on aquatic macrophyte diversity in seasonal wetlands. Applied Water Science, 9 (12): $1-8$.

Riera, JL; Ballesteros, E; Pulido, C; Chappuis, E; Gacia, E (2017). Recovery of submersed vegetation in a high mountain oligotrophic softwater lake over two decades after impoundment. Hydrobiologia, 794: 139-151.

Riis, T; Olesen, B; Clayton, JS; Lambertini, C; Brix, H; Sorrell, BK (2012). Growth and morphology in relation to temperature and light availability during the establishment of three invasive aquatic plant species. Aquatic Botany, 102: $56-64$.

Rothausler, E; Gomez, I; Karsten, U; Tala, F; Thiel, M. (2011). Physiological acclimation of floating Macrocystis pyrifera to temperature and irradiance ensures long-term persistence at the sea 
surface at mid-latitudes. J. Exper. Mar. Bio. Ecol. 405: $33-41$.

Samecka-Cymerman, A; Kempers, A (2007). Heavy metals in aquatic macrophytes from two small rivers polluted by urban, agricultural and textile industry sewages SW Poland. Arch. Environ. Contam. Toxic. 53: 198-206.

Schneider, S; Melzer, A (2004). Sediment and water nutrient characteristics in patches of submerged macrophytes in running waters. Hydrobiologia, 527: 195-207.

Subhas, AG; Sarabhai, MS; Jayaprakesh, NA (2016). Changes in the macrophytic species composition in relations to water chemistry of the wetland. Inter. J. Animal Breed. Gen. 3(7): 143 - 147.
Ter Braak CJF (1986). Canonical correspondence analysis: a new eigenvector technique for multivariate direct gradient analysis. Ecology, 67(5):1167-1179.

Wetzel, RG (2001). Limnology: Lake and River Ecosystems. San Diego, CA: G. P. Publishing Academic Press.

Wrona, FJ; Prowse, TD; Reist, JD; Hobbie, JE; Levesque, LMJ; Vincent, WF. (2006). Climate change effects on aquatic biota, ecosystem structure and function. AMBIO: J. Human Environ. 35: 359 - 369.

Zhang, Q; Xu, YS; Huang, L; Xue, W; Sun, GQ; Zhang, MX (2014). Does mechanical disturbance affect the performance and species composition of submerged macrophyte communities? Scientific Reports, 4: 2045-2322 